\title{
Hydrocarbon potential of the Ural-African transcontinental oil and gas belt
}

\author{
Vladimir S. Litvinenko ${ }^{1} \cdot$ Aleksandr V. Kozlov ${ }^{1} \cdot$ Valentin A. Stepanov $^{1}$
}

Received: 2 July 2015/ Accepted: 17 April 2016/Published online: 19 May 2016

(C) The Author(s) 2016. This article is published with open access at Springerlink.com

\begin{abstract}
Recently, several major hydrocarbon fields have been discovered in the Ural-African transcontinental oil and gas belt. These include the Pobeda field in the Kara Sea (338 billion $\mathrm{m}^{3}$ of gas, $>100$ million tons of oil), the Velikoe field in the Astrakhan region ( 90 billion $\mathrm{m}^{3}$ of gas, 300 million tons of oil), and the Galkynysh gas field in Turkmenistan (the world's second largest, after North Dome). There have also been a number of oil and gas finds in East Africa. All of those corroborate the idea of the Ural-African transcontinental oil and gas belt being a planetary structure hosting unique hydrocarbon concentrations. Analysis of the belt's metallogeny shows that large and super-large deposits of metallic and nonmetallic minerals are concentrated in an axial zone, highlighting the large-scale redistribution of energy and matter in the Earth's crust and mantle. These processes are most active in the rift structure where they come together to form the Ural-African transcontinental oil and gas belt. The process that formed the recently identified hydrocarbon deposits within the modern rift structure-the East African Rift system - can be seen as an embryonic stage in formation of oil-gas accumulations. The East African Rift petroleum discoveries are characterized by the continuous flow of hydrocarbons and its short-term residence in local traps. This makes finding major hydrocarbon deposits there unlikely. The potential for large deposits is more likely where large accumulations of hydrocarbons are overlapped
\end{abstract}

Valentin A. Stepanov

vstepanov@spmi.ru

1 The National Mineral Resources University (Mining University), 21st Line, Saint Petersburg, Russia by later sedimentary strata, a situation seen offshore of East Africa.

Keywords The Ural-African transcontinental oil and gas belt - Oil and gas bearing - Rifting - Oil- and gas-bearing prospects

\section{Introduction}

The Ural-African transcontinental oil and gas belt (UATB) was identified based on analysis of the geological and geophysical features of the world's largest oil and gas provinces. Most of the analysis of the Russian part of the belt was done in connection with the search for solutions to the problem of expanding the resource base of oil and gas in Russia (Smyslov et al. 2003). A worldwide assessment of sedimentary basins with the potential for the discovery of profitable new large oil and gas deposits showed that such basins are primarily associated with the rift structures to the west and east of the Ural-Novaya Zemlya fold system, Russia (Smyslov et al. 2003; Litvinenko and Kozlov 2014). A number of major oil and gas basins are located there including the Western Siberian, Timan-Pechora, Volga-Ural, and Caspian basins. These basins form the northern segment of the Ural-African transcontinental oil and gas belt, a belt characterized by a high concentration of hydrocarbon deposits. This paper presents the results of a recent reanalysis of the Ural-African transcontinental oil and gas belt and looks at the geological features of this structure in Russia and abroad. New oil and gas fields have been discovered in this structure in recent years, and the nature of this unique area of hydrocarbon concentrations is examined. 


\section{New discoveries}

Analysis of the structure of the Ural-African transcontinental oil and gas belt shows that the total resource endowment of the large hydrocarbon deposits there exceeds $50 \%$ of the known world reserves. A little more than 10 years have passed since the belt was identified as a single transcontinental oil and gas structure (Aplonov and Lebedev 2010), and during this period, numerous new deposits have been discovered allowing further analysis of the patterns of their formation and emplacement.

No major oil deposits had been discovered in Russia for more than 20 years until 2013. The last previous discovery was that of the Vankor oil field in 1988 (recoverable reserves more than 500 million tons), but in 2013-2014, two new oil fields were found, both rather rich. These were the Pobeda field on the Kara Sea shelf and the Velikoe field in the Astrakhan region. Both are in the Ural-African transcontinental oil and gas belt.

The new Pobeda (Victory) field was discovered in the Kara Sea in September 2014 by Rosneft and Exxon Mobil. It contains light high quality oil comparable to Siberian Light. Preliminary assessment of the deposit concluded that it contains 338 billion $\mathrm{m}^{3}$ of gas and at least 100 million tons of oil. The University-1 borehole tested just one of the traps within the vast petroleum tract expected to be found there, the oil strike has been obtained at the depth $2100 \mathrm{~m}$. The "University" structure has a total area of $1200 \mathrm{~km}^{2}$ with the amplitude of the trap fold being $550 \mathrm{~m}$. Resources for the entire structure are estimated at 1.3 billion tons oil equivalent (State Commission... 2014).

The Velikoe (Great) oil field was discovered in 2012 in the Astrakhan region by the junior AFB Oil and Gas Company. Based on exploratory drilling, the initial evaluation was 42.3 million tons of oil but subsequent exploration work has raised the estimate of probable and possible reserves to 300 million tons of oil and 90 billion $\mathrm{m}^{3}$ of gas. The oil is light and the gas is low in hydrogen sulfide, but the well has revealed a complex geological structure that may increase development costs. Depth of the reservoir occurrence in the middle Carboniferous is $4870-5150 \mathrm{~m}$. The maximum level of production rate may reach 30 million tons per year (Solodovnikova and Melnikov 2014).

In August 2013, the Galkynysh deposit in Turkmenistan was put into commercial production. This super-giant gas field is located in southeastern Turkmenistan close to the Iranian and Afghan borders. The area is adjacent to the Murghab oil and gas area, a large eponymous Late Mesozoic basin located on the southern tip of the young postPaleozoic Turan plate. According to Gaffney, Cline and Associates (UK), Galkynysh has the second largest petroleum equivalent resources in the world after the North Block Complex-South Pars reserves in Qatar/Iran. Galkynysh hosts the world's largest natural gas reserves, 26.2 trillion $\mathrm{m}^{3}$, and related oil reserves of about 300 million tons. Depth of the reservoir occurrence in Upper Jurassic is 3500-5100. Gas is acid, and annual production is limited by capacity of the gas refinery. Processing plants are constructed with planned production rate 30 billion $\mathrm{m}^{3}$ per year (Daily review... 2013).

Large-scale oil and gas exploration started in the East African Rift basins in 1982 (Yapaskurt 1989), but positive results were obtained only during the last 12 years when large oil reserves were discovered in the basins of the western branch of the East African Rift system (Davison et al. 2014). In 2002, the Turaco-1 well, drilled near Lake Albert by Heritage Oil, produced its first oil. Twenty oil fields were discovered in and to the east of the Albertine Rift since then with estimated reserves of more than four billion barrels (600 million tons). The discovery of such relatively large reserves dispels the belief that there is no oil in this region of Africa. Development of petroleum reserves there is economically feasible, and the region is capable of commercial production.

These large deposits attest to the hydrocarbon potential of the UATB and raise questions about the origin of this structure. This study considers the whole of the region, the distribution of not only hydrocarbons deposits but metallic and nonmetallic mineral deposits as well. Information on new oil and gas basins in the UATB will shed new light on its hydrocarbon potential (Tyrrell et al. 2015; White 2014).

\section{Rifting, ore genesis, and oil formation}

It was noted earlier that all the Russian basins in the UralAfrican transcontinental oil and gas belt share some common features favorable for the formation of large oil and gas deposits (Smyslov et al. 2003; Litvinenko and Kozlov 2014). Some of these features are:

- In some cases, the basins contained extremely thick accumulations of sediment, had high sedimentation rates, and contained formations with abnormally high organic carbon contents;

- The basins overlie a wide range of rift structures of different ages in their basement complexes and were subject to intense heat and mass transfer associated with rifting. This resulted in fluid warming of the sedimentary cover and the likely supply of additional hydrocarbons from the depths;

- The basins contain a variety of the trapping structures and impermeable cap rocks necessary for the formation of oil and gas deposits; 
- The basins shared favorable geodynamic factors such as temperature, pressure, and tension and compression processes at the crustal scale that combined to ensure the formation of large-scale hydrocarbon deposits. In part, these conditions allowed the formation of singular petroleum deposits with oil and gas horizons hundreds or thousands of meters in thickness.

To study the nature of such an accumulation of hydrocarbons in a relatively narrow structure, it was necessary to consider the structure in its entirety from the Barents Sea to southeast Africa. As was noted earlier (Smyslov et al. 2003; Litvinenko and Kozlov 2014), the hydrocarbon deposits are clearly spatially associated with the rift structures. This spatial association has also been noted by a number of other researchers (Syvorotkin and Pavlenkova 2013; Verba 2007; Predtechenskaya and Fomichev 2011; Aplonov and Lebedev 2010).

The UATB is a complex ensemble of local rifts of different sizes associated with a single planetary-scale linear structure. The position of this structure coincides with a global gravitational anomaly. This gravitational "step" marks a relatively narrow strip between thin mantle beneath the eastern part of the Eurasian continent (east of the Urals) and thick and dense mantle to the west (Fig. 1).
The UATB also includes the Ural-Oman lineament, a global linear structure first identified by A.P. Karpinsky in 1894. He described it as a system of meridian-parallel displacements running along the Ural mountain range to the lower reaches of the Amu Darya River. The modern interpretation sees the lineament as a broad strip more than $300 \mathrm{~km}$ in width that goes from Pai-Khoi at the northern end of the Ural Mountains and follows the Urals along the $60^{\circ}$ meridian across the Karakum Desert and the Iranian Plateau. After it passes the Gulf of Oman, it turns to the southwest and reaches the west coast of Madagascar. Its total length is about $15,000 \mathrm{~km}$ (Bush 1983). Khain (2000) saw its northern fragment as one of the world's largest Barents-Caspian oil and gas belts. The Urals folded zone is considered to be the largest branch of the world system of mobile belts, and large and super-large mineral deposits are associated with those belts (Zoloev et al. 2012).

It is important to stress that the rift structures that constitute the individual segments of the Ural-African transcontinental oil and gas belt have different ages, ages ranging from Mesoarchean to Cenozoic. The ages of rift structures' activation can be assessed by determining the age of formation of the metallic mineral deposits they host, especially large and super-large deposits. These deposits are formed in high gradient, high-energy systems. We

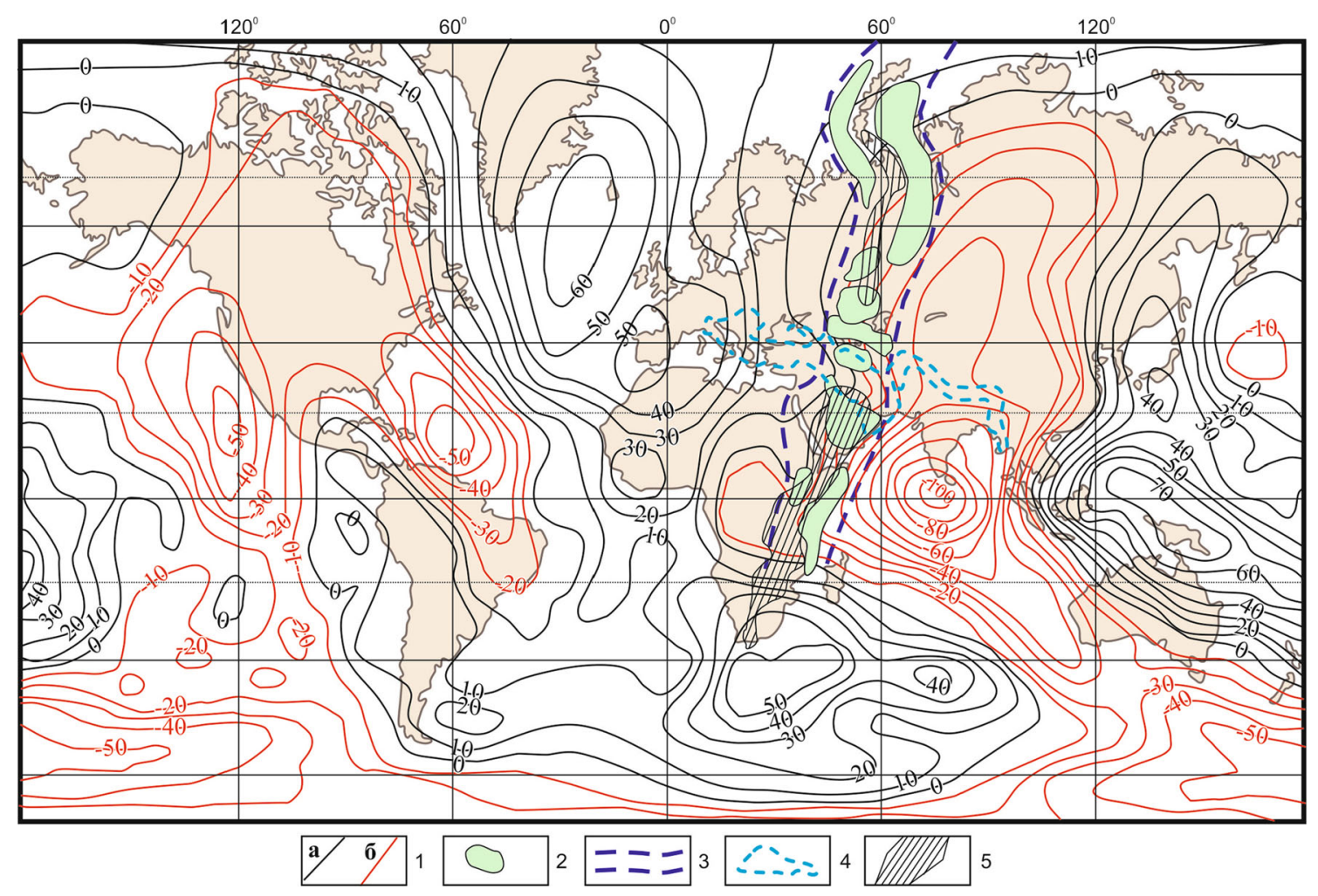

Fig. 1 Connection between the transcontinental belt of high oil and gas potential and the global step in the earth's gravitational field (Smyslov et al. 2003). 1 Isolines of the gravitational potential (a positive, b negative values); 2 sedimentary basins with established oil and gas content; 3 transition boundaries (stages) of the Earth's gravitational potential, from the thin deep mantle masses to more dense ones; 4 the Mediterranean mobile belt; 5 axial zone of mixed age rifting) 
analyzed the Ural-African transcontinental oil and gas belt along its entire length from this perspective and compiled data on the ages of the large and super-large metallic mineral deposits that are part of the belt.

There is a Mesoarchean sedimentary rift basin and the giant Witwatersrand gold-uranium deposits of the same name in South Africa at the southern tip of the belt. There are no hydrocarbon deposits in that area, but thucholite (a complex of organic matter and uraninite) does occur in the Witwatersrand deposits. Thucholite has been regarded as the product of the conversion of petroleum hydrocarbons (Hoekstra and Fuchs 1960). One of the models for gold ore bodies in the Witwatersrand proposes that fine detrital gold accumulated on microbial or algal mats in a delta environment. The relevant observation here is that organic carbon accumulations took place in the Mesoarchean era and that it seems likely that this biogenic carbon was preserved for more than three billion years.

North of the Witwatersrand depression, there is a unique geological body in Zimbabwe, the Great Dyke. The Great Dyke is a linear Neoarchean rift intrusion about $550 \mathrm{~km}$ long and 5-11 km thick whose strike is nearly north-south. It hosts super-large chrome and platinum group element ore deposits. Rare-metal mineralization at the super-large Bikita pegmatite deposit in Zimbabwe is also dated as Neoarchean.

Many large deposits in the southern part of the African continent are of Paleoproterozoic age. These include South Africa's largest deposits at the layered Bushveld Complex where there are important deposits of chromium, platinum group metals, copper-nickel, and iron-titanium ore. The Palabora carbonatite-hosted deposits of copper, iron, and zirconium, and the super-large Postmasburg manganese deposits are also Paleoproterozoic in age.

The "Premier" kimberlite pipe, which has produced some of the world's largest gem diamonds, is of the Mesoproterozoic age. It is telling that it is located on the southern periphery of the Bushveld Complex in alignment with the meridian Great Dyke, which clearly links the formation of the pipe to rifting processes.

The Neoproterozoic age in the rift zone is marked by the formation of the largest copper belt in the world, which stretches along the border of Zambia and the Democratic Republic of Congo (DRC). The Bingo and Lueshe carbonatite complexes, with phosphate and niobium mineralization, and the giant Manono pegmatite, all in the DRC, are also Neoproterozoic in age.

Endogenous ore formation decreased during the Phanerozoic, but platform mantle activation clearly manifested itself in the form of large diamond-bearing kimberlite bodies such as the Paleozoic Venetia pipe in South Africa, the Mesozoic Orapa and Jwaneng pipes in Botswana, and the Cenozoic Mwadui pipe in Tanzania. Those manifestations of ore genesis of different ages in the southern part of the structure show the long history of its endogenous activity over more than 3 billion years. The southern part of this structure in Africa is the youngest and the northern part the oldest.

The East African rift (Fig. 2), which is a natural laboratory for this study, is the youngest section of the rift system - the rift system is in its infancy. The rift is active and still evolving (Wood and Guth 2014).

The western branch of the rift stretches from Lake Albert to the south and includes the African Great Lakes. The eastern branch, the Kenyan Rift, runs across Kenya from north to south and fades out in Tanzania. There is also a system of numerous smaller fractures (grabens). Lake Victoria is between the western and eastern branches of the rift. The rift structures are separated at this point and are thought to envelop a block of ancient metamorphic crust.

The branches represent an integral system of rifts, and yet they differ significantly. The western branch rifts are more developed, filled with great masses of sediment, and covered by the waters of the African Great Lakes including Lake Tanganyika (the second deepest lake in the world). The deposits of hydrocarbons are associated with this part of the East African Rift system. Volcanic activity is more prominent in the eastern branch.

The East African Rift system is clearly segmented and can be separated into individual units (Davison et al. 2014). Faults that define individual rifts have five main orientations, and commonly, the orientation coincides with the direction of Precambrian shear zones or rifts in the PermoTriassic Karoo Super-group. The Karoo formed in a huge basin in the southern part of Africa, but Karoo fragments can be found as far north as Kenya. This means that the Karoo sedimentary rift basin used to stretch along the East African rift, but its northern part has been significantly modified. In summary, the modern East African Rift system is Precambrian, it became active in the Late Paleozoic and Early Mesozoic, and it continues to develop today.

The northern part of the East African Rift system, represented by the Ethiopian Rift, forms a triple junction where the Red Sea, Gulf of Aden, and the Ethiopian rifts join (the Afar Triangle). Further to the north, the UATB links to the Mediterranean mobile belt (see Fig. 1), and some might propose that the best is broken there.

However, the near-meridian orientation of the Caspian Sea and the orientation of the associated oil- and gasbearing structures support the idea of a link between the African part and the Urals part of the belt. The largest deposits of hydrocarbons in the Persian Gulf, the Ghawar, North, and other fields, also have meridian orientations and only take on a northwestern orientation at the junction with the Zagros Alpine folded system (Fig. 3). A similar situation exists in the South Caspian basin (Fig. 4). Two trends 


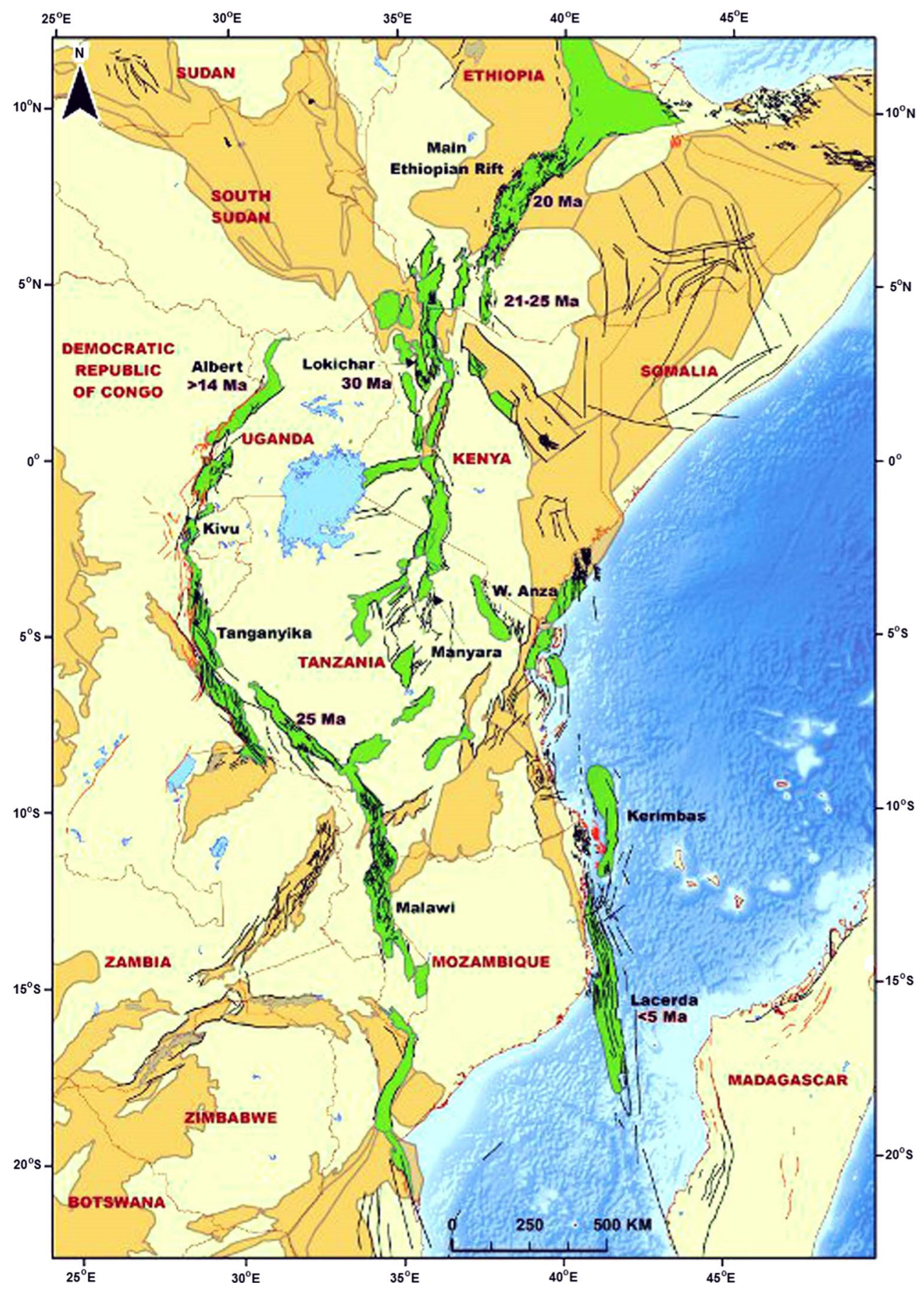

Fig. 2 Map of the East African Rift system showing rifts of different ages (from Wood and Guth 2014)

in the orientations of oil-bearing structures are clearly seen there: a near-meridional trend following the orientation of the Ural-African transcontinental oil and gas belt and northwestern trend in parallel to the structures of the Alpine Mediterranean mobile belt.

The northern part of the UATB, located mainly in Russia, is closely connected to the Urals metallogenic zone (Zoloev et al. 2012). Geologically, this zone is a fold system in a domain of continental expansion.
The crustal structure of the region shows that the initial formation of the Urals rift structure and its subsequent development occurred on continental crust that was 30-50 km thick (Berlyand 1982; Zoloev et al. 2012; Popov and Rapoport 1996). The onset of rifting is Riphean (Mesoproterozoic) in age, when the East European-Siberian platform split along sub-meridian schisms in the foundation. This started the formation of the intra-continental rift. Chromite ore (in the Saranovskaya intrusion) and titanium 
Fig. 3 Change in orientation of oil- and gas-bearing structures at the junction of the UATB and the Zagros fold system (from Maksakovsky 2009). Oil and gas fields: 1 South Pars, 2 North Dome, 3 Ghawar, 4 Abqaiq, 5 Qatif, 6 Berry, 7 Manifa, 8 Saffaniya, 9 Rumeila, 10 Mansouri, 11 Marui, 12 Aghajari

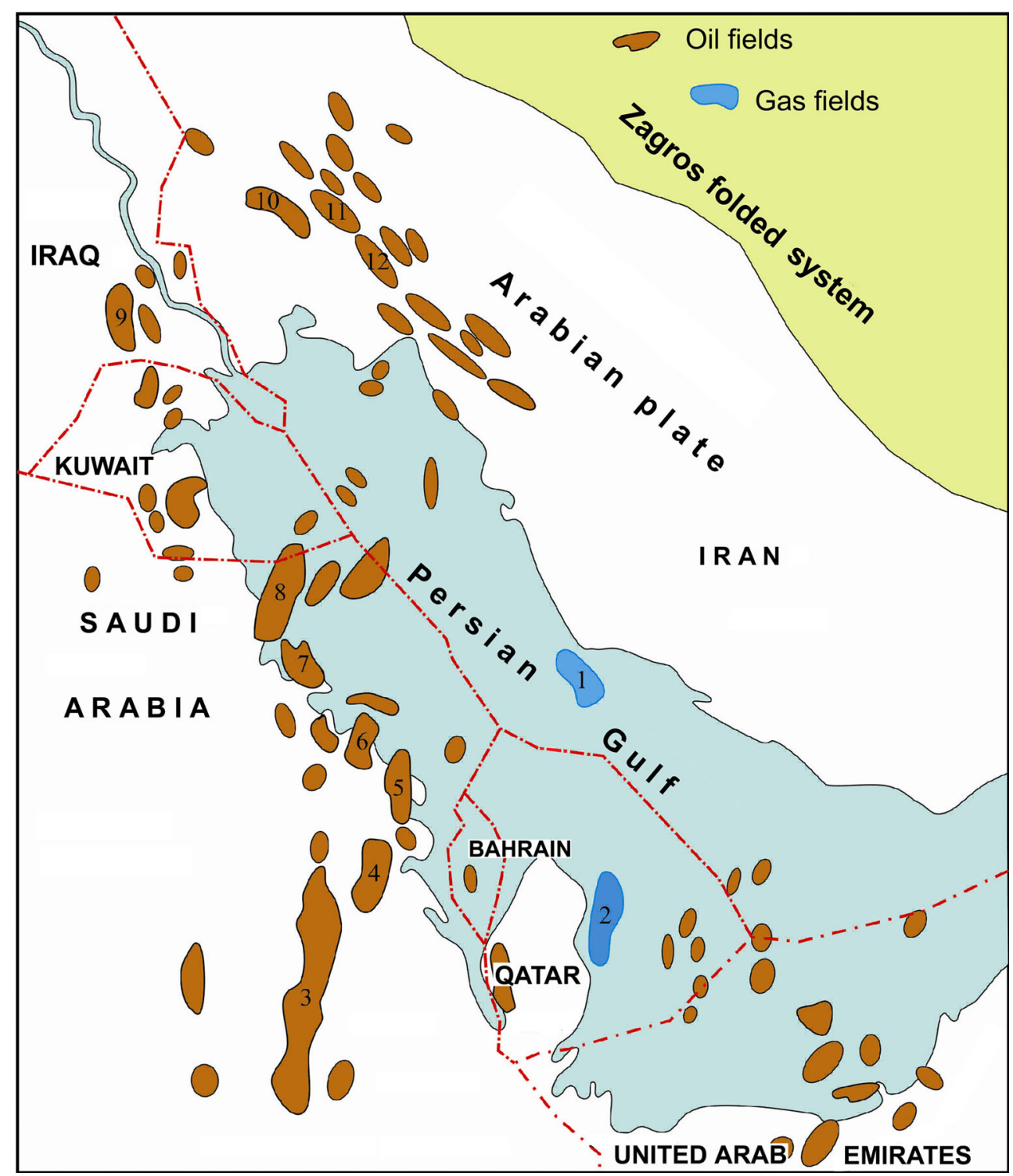

magnetite segregations (in the Kusinsk-Kopansky group) are connected to ultrabasic and basic magmatism of this period. Numerous small deposits of gold, tungsten, molybdenum, and more complex ores are associated with acidic magmatism primarily within the Central Ural uplift. Siderite iron ore (the Bakal group) and magnesite deposits (the Satka group) were formed in rifting sedimentary basins of this age.

An increase in tectonic activity at the start of the Paleozoic resulted in an increase in the frequency of faulting and the formation, in the Tagil-Magnitogorsk depression, of a volcanic belt. In a number of respects, this volcanic belt is similar to an island-arc, but geophysical data lead us to classify the proposed island-arc structure as an intracontinental rift. A substantial increase in the coefficient of the basicity of the crust resulted from the introducing of large volumes of mafic and ultramafic magma (Zoloev et al. 2012). This has led to a significant change in the metallogeny of the Magnitogorsk area of the Urals fold zone. Within this zone, large deposits of chromite and platinum group elements have been emplaced along with massive sulfide volcanogenic-sedimentary deposits and magmatic deposits of iron-titanium-vanadium ores.

The Ural fold system is unique in its metallogeny. This is expressed by the wide range of lithophile, chalcophile, and siderophile metallic minerals and the many types of nonmetal raw materials (precious stones, salts, etc.) found there. Its uniqueness is emphasized by the existence of many large and super-large mineral deposits. There is no other such system in terms of scale and the range of metallogenic specialization on the planet (Zoloev et al. 2012).

The reason the Urals structural and metallogenic zone is unique is that its long period of development involving the 
Fig. 4 Map showing strike of structures in the southern Caspian junction of the UralAfrican transcontinental oil and gas belt and the Mediterranean mobile belt (from Astafyev et al. 2010, in authors' reduction)

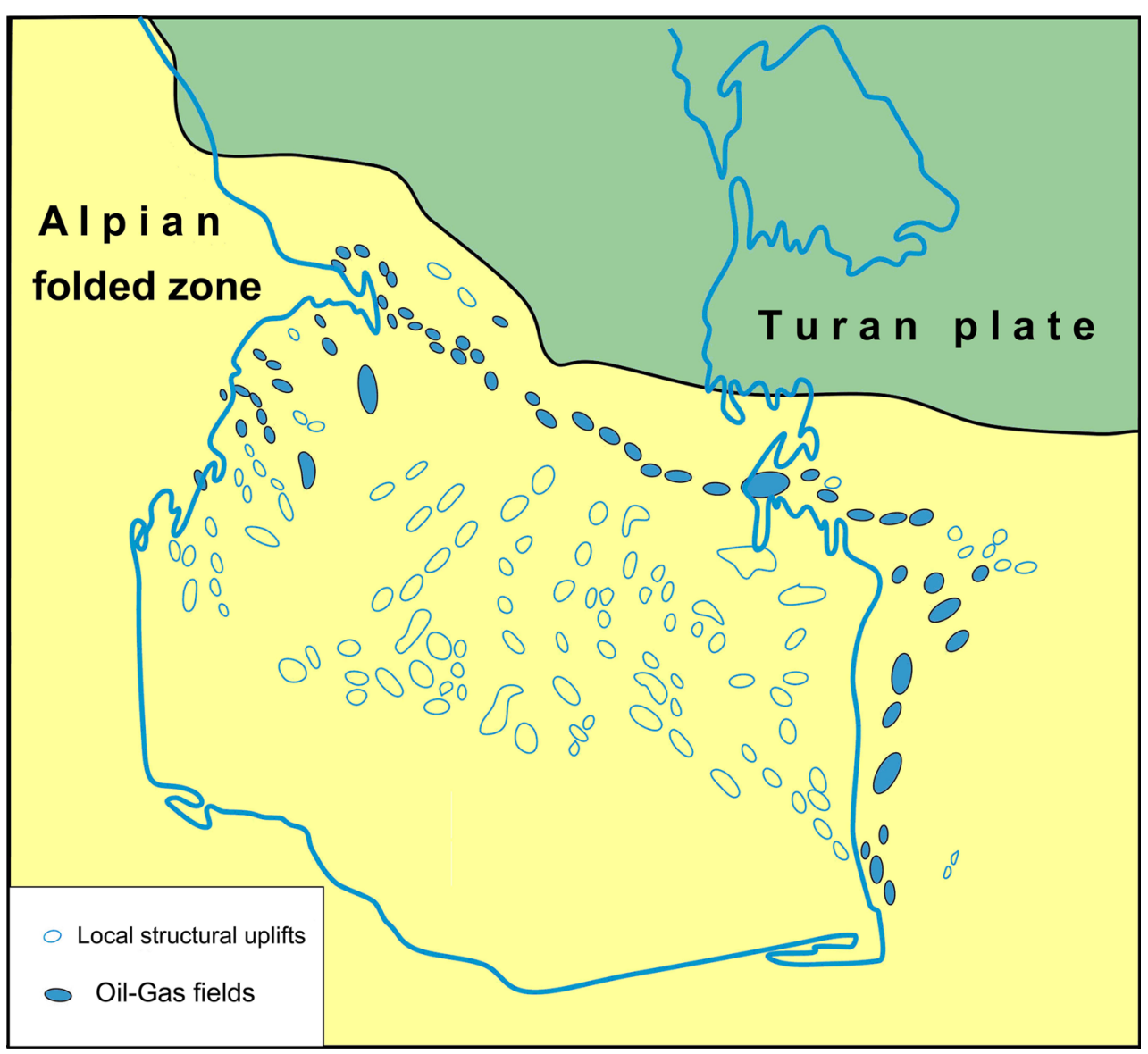

formation of a meridian fault and subsequent metamorphism and folding promoting the formation of polygonal and linear rift structures with an exceptionally high oil and gas content. The Urals can be viewed not only as an independent structural geological and metallogenic province but also as the axial zone of the wider and longer Ural-African transcontinental oil and gas belt. Crustmantle interaction with extensive development of magmatism and fluid-hydrothermal activity were most active and were most concentrated in the Urals fold zone. On the margins of this axial zone, under conditions of a lower thermal gradient and more scattered crust-mantle heat and mass transfer, deep sedimentary basins and oil and gas fields were formed.

Analysis of the literature allows us to confirm that the axial zone of the UATB is ancient, most likely Achaean, but separate sections experienced activation at a later time. At some well-known ore sites, metamorphic fragments of carbonaceous matter of biogenic origin are quite well preserved (thucholite at the Witwatersrand). The youngest oil and gas are present in the central area of the belt, in the East African Rift system, the region of the Persian Gulf, and in the South Caspian basin.
The modern East African Rift system can, by its structure, be seen as a model for analysis of the specific features of the interior of the UATB as a whole. Like the whole Ural-African transcontinental belt, the East African Rift system is also segmented and has a complex arrangement of its separate components aligned in a constant meridian direction.

In the East African Rift system, there are a number of active volcanoes, especially along its eastern branch, but there are also hydrocarbon deposits. During the first stages of exploration for oil and gas there, work was geared toward footwall traps in rotated fault blocks. According to the results of the drilling, the main role was played by the "hanging wall" traps (or tectonic screens; Fig. 5), traps "leaning" on the hanging wall of the structure (Davison et al. 2014).

The major discoveries in the Lake Albert area and in the Lokichar District, the Mputa, Kingfisher, and Ngamia fields are linked to such structures. The traps of this type have developed near faults in the thicker cap rocks, which in a region with such a high level of seismic activity, like the East African Rift system, means there can be flow channels for hydrocarbons along faults into the structural 


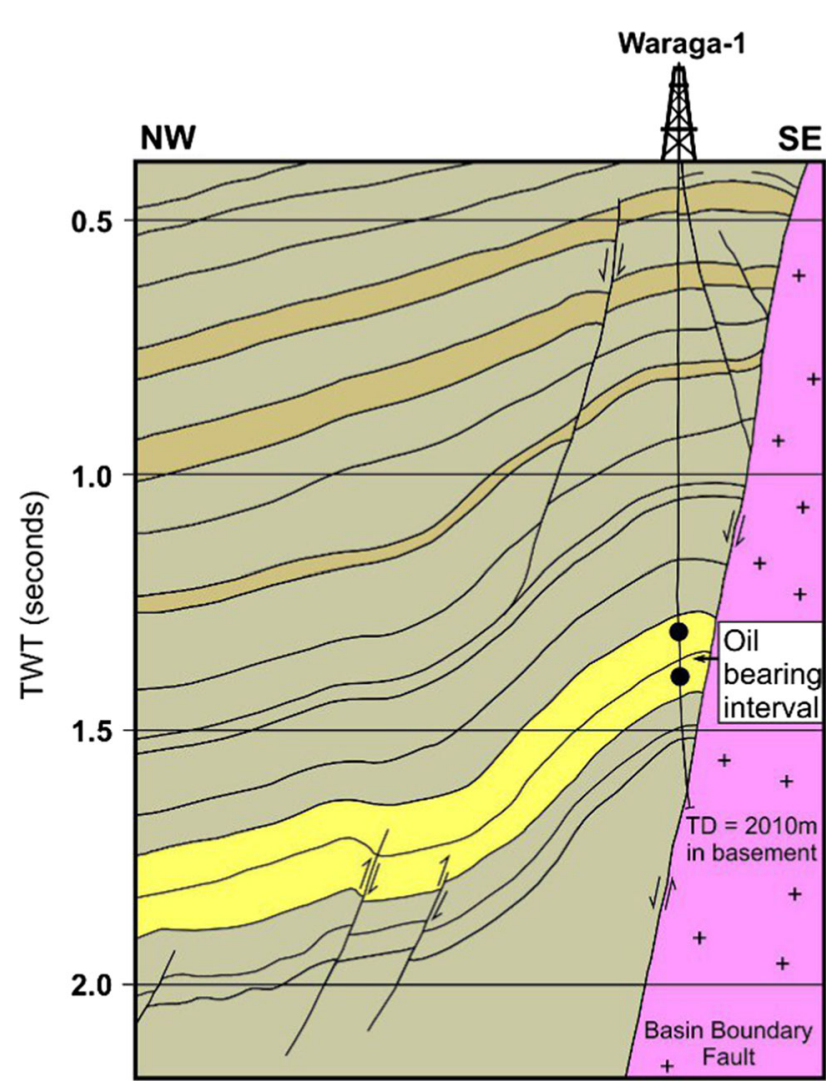

Fig. 5 Cross section showing an example of a tectonic screen traps: Albert Lake rift, Uganda. Not to scale except vertical scale is seismic two-way travel (time; from Davison et al. 2014)

traps. This is why it is thought that one of the important factors promoting the productivity of the structure is the active movement of oil along the fractured and porous flow line that ensures a continuous feed of petroleum to the reservoir (Davison et al. 2014).

It is characteristic that both in the Albert rift and in the Lokichar region (and in general in the region up to southern Mozambique), there are many oil seeps at the surface. Naturally, it is worth considering these as exploration targets when evaluating the potential of other rift basins of the East African Rift system.

The accumulation of hydrocarbons in tectonic screen traps in modern rifts can be considered as the embryonic stages in the formation of oil and gas fields. The rapid accumulation of coarse terrigenous sediments with a range of organic material determines the oil-generating and flow line properties of the rift-related sedimentary formations.

The greater heat flow in rift-related sedimentary basins enhances rapid transformation of the organic matter, and the high seismic activity enables the migration of newly formed liquid and gaseous hydrocarbons. However, the active rift regime is not good for the formation of strong cap rocks, which is detrimental to the formation of major oil and gas fields. Conditions favorable for the generation of strong cap rocks only arise during the fading stages of rift orogenesis, conditions like those on the eastern African shelf and the South Caspian basin today. In both those locations, regional cap rocks can be formed. In addition, roof structures there are good for the accumulation of hydrocarbons, and rift-related tectonic activity is minor.

The following features of their structure and geological development determine the confined nature of the oil and gas basins in rift-related structures.

1. Rift-related sedimentary basins are characterized by rapid sedimentation because they are in regions of active tectonism.

2. Accumulation of material in rift-related depressions takes place not only by sedimentation of clastic material from its sides but also the inflow of substances and energy of deep-seated origin. This inflow promotes the intensive development of diverse kinds of biota and continuous and intensive accumulation of organic materials.

3. The combination of rapid sedimentation and the warm flows from below into the rift zone lead to the organic material being effectively modified soon after sedimentation. This creates the optimal conditions for petroleum generation.

4. The structural dynamics of the rift are conducive to the formation of open structures. This leads to the possibility of vertical migration of fluids in fault zones.

5. The highest concentrations of oil and gas should be expected to be formed after the second accumulation of hydrocarbons, accumulations that form after the covering of rift-related sediments by later marine deposits. These large concentrations are formed by regionally distributed reservoirs and cap rocks.

\section{Conclusions}

1. The rift-related structure that controls the Ural-African transcontinental oil and gas belt (UATB) was first formed in the Mesoarchean and has been periodically activated since then. It is active today. The locations of the different rifts within its boundaries are related to more ancient crustal structures.

2. The axial part of this structure, characterized by intensive crust-mantle processes with active magmatism and both endogenous and exogenous ore genesis, is called the "energy axis" of the UATB. In the interval from the Mesoarchean period to the present time, concerted powerful flows of deep energy took place in this zone. These flows are indicated by the magmatic fluid fields and the even more intense flows of solar power that are manifested in the great 
development of the biosphere with the resulting accumulations of organic matter.

3. The structures of the UATB meet younger, closely spaced zones in which different episodes of tectonomagmatic events have taken place (the Dnepr-Donetsk aulacogen, the Mediterranean mobile belt, the Zagros fold, and thrust belt). In these areas, the tectonic processes within the boundaries of the UATB have caused the rapid embedding of separate tectonic blocks and the formation of potent sedimentary masses with a high hydrocarbon potential. Oil- and gas-bearing structures in the basins formed there have features characteristic of both structures.

4. The accumulation of hydrocarbons in traps in modern rifts can be seen as an embryonic stage of the formation of oil and gas fields, which are later preserved against a background of general downwarping and attenuating tectonic activity. The oil and gas generating systems within the boundaries of the East African rift zone fall into this category. Fields linked to modern rifts are unlikely to host significant hydrocarbon reserves owing to the dynamic character of the local geology. During the last stages of rift evolution, these local hydrocarbon accumulations can be covered with later marine sediments and secondary traps on a larger scale can be formed. The outlook for identifying such oil- and gas-bearing structures is good on the East African shelf where offshore discoveries have already been made of Tanzania and Mozambique. The hydrocarbon fields in the South Caspian depression occupy a similar position.

Acknowledgments The authors hold many grateful memories of Professor Anatoliy Andreevich Smyslov-an outstanding Russian geologist - who was the first to attract their attention, more than a decade ago, to the unique global-scale meaning of the structural zone following the Urals. Recent discoveries have confirmed his brilliant foresight.

Open Access This article is distributed under the terms of the Creative Commons Attribution 4.0 International License (http:// creativecommons.org/licenses/by/4.0/), which permits unrestricted use, distribution, and reproduction in any medium, provided you give appropriate credit to the original author(s) and the source, provide a link to the Creative Commons license, and indicate if changes were made.

\section{References}

Aplonov S, Lebedev B (2010) Oil-ore-genesis: spatial and temporal relation of giant deposits. Sci World, Moscow (in Russian)

Astafyev D, Medvedev N, Akhiyarov A et al (2010) Tectonicdynamic and lithofacies of the oil and gas bearing South Caspian depression. Problems of resource management of gas-producing regions of Russia to 2030. Gazprom Vniigaz, Moscow, pp 84-93. Retrieved from http://vesti-gas.ru/sites/default/files/ attachments/perspektivy_razvitiya_01.pdf (in Russian)

Berlyand N (1982) Division Ural-type structure of the earth crust. Sov Geol 11:78-89 (in Russian)

Bush V (1983) Systems of transcontinental linear structures of Eurasia. Geotectonics 3:87-92 (in Russian)

Daily review of Turkmenistan news (2013) Retrieved from http:// russian.eurasianet.org/node/59954 (in Russian)

Davison I, Steel I, Taylor M et al (2014) Exploration in the East African Rift System. GeoExPro 11(5):26-31. http://www. geoexpro.com/articles/2014/11/exploration-in-the-east-africanrift-system

Hoekstra H, Fuchs L (1960) The origin of thucholite. Econ Geol $55: 1716-1738$

Khain V (2000) Barents-Caspian oil and gas belt—one of the biggest in the world. Fundamentalny bazis novikh techologii neftyanoi I gazovoi promishlennosti. Nauka, Moscow, pp 17-22 (in Russian)

Litvinenko V, Kozlov A (2014) The Ural-African Transcontinental Oil and Gas Belt. J Pet Environ Biotechnol 5:2. doi:10.4172/ 2157-7463.1000174

Maksakovsky V (2009) Geographic picture of the world, book 2. "Drofa" Edition, Moscow (in Russian)

Popov V, Rapoport M (1996) Tectonic-magmatic development of the Urals: new aspects of an old problem. Izv Vuzov Geol i razv 4:3-21 (in Russian)

Predtechenskaya E, Fomichev A (2011) Influence of faulting on the temperature regime and catagenetic transformation of Mesozoic deposits of the West Siberian plates. Neftegazovaya geologiya. Teoriya i praktika 6. Retrieved from http://www.ngtp.ru/rub/4/2_ 2011.pdf (in Russian)

Smyslov A, Kozlov A, Yu V (2003) The issue of oil in Russia in the XXI century and paths towards solutions. Mining Institute Digest, Saint-Petersburg, p 12 (in Russian)

Solodovnikova A, Melnikov K (2014) Ministry has declared about Velikoe oil field. Kommersant. Retrieved from http:// kommersant.ru/doc/2454158 (in Russian)

State Commission on mineral reserves has confirmed the Pobeda oil field discovery (2014) Retrieved from http://neftegaz.ru/news/ view/132896 (in Russian)

Syvorotkin V, Pavlenkova N (2013) The world's rift system and oil and gas bearing belts of the planet: a new look at the geotectonic position of the Caspian region and the possibilities for monitoring. Almanakh Prostranstvo i Vremya 4(2):123-134 (in Russian)

Tyrrell M, Jielai X, Kuitai S et al (2015) A new oil play in East Africa. GeoExPro 11:6

Verba M (2007) Modern bilateral crustal stretching in the BarentsKara region and its role in the evaluation of the outlook for oil and gas bearing possibilities. Nefetgazovaya geologiya. Teoriya i praktika 2. http://www.ngtp.ru/rub/4/026.pdf (in Russian)

White K (2014) East Africa. Rays of a New Dawn. GeoExPro. http:// www.geoexpro.com/articles/2014/06/east-africa-rays-of-a-newdawn

Wood J, Guth A (2014) East Africa's Great Rift Valley: a complex rift system. Michigan Technological University. http://geology. com/articles/east-africa-rift.shtml

Yapaskurt L (1989) Oil exploration in the East African rift system. Geol Oil Gas 8:56-57 (in Russian)

Zoloev K, Dodin D, Koroteev V, Krivko T (2012) Minerageny of the Urals fold belt and fluid sulfurization of mantle hydrocarbons of the West Siberian sedimentation basin and its plate foundation. Lithosphere 4:173-189 (in Russian) 